\title{
Editorial
}

Journal of Innate

Immunity
J Innate Immun 2016;8:109-110

DOI: $10.1159 / 000444614$
Published online: March 1, 2016

\section{Gone with the Wind - Innate Immunity and Airway Inflammation}

In this issue of the Journal of Innate Immunity, several articles dealing with innate immune responses and inflammation in the airways are presented. Some of the cellular players involved are known for a long time. Early discoveries were made by Paul Ehrlich (1854-1915) who, together with Elie Metchnikoff (1845-1916), is recognized as the founder of innate immunity. In their review, Valent et al. [1] describe the life and career of this outstanding scientist. An example of Paul Ehrlich's discoveries is the use of eosin, a bright red dye that stains cationic proteins due to its acidic nature, on cells and tissues. $\mathrm{He}$ introduced the term 'eosinophil' to describe these unique cells with granules (which he called $\alpha$-granules) showing an affinity for this dye.

The presence of eosinophils is a hallmark of allergic asthma, and eosinophil levels are also typically raised in the blood and tissue during helminthic infestation. However, despite many years of research, their role in allergic inflammation is still not elucidated [2]. During airway inflammation, initial innate immune responses can be divided into a sequence of events where resolution is important [3]. A prolonged and systemic inflammatory response may affect local host defense, resulting from decreased granulocyte activation as well as the production of reactive oxygen species (ROS) $[4,5]$. After ROS recruitment to the site of inflammation, where CXC chemokines play an essential role, ROS production is an important arm of innate host defense executed by neutrophils [6]. In this issue, Choudhary et al. [7] show that endogenous nuclear ROS sensors transmit nuclear signals that coordinate outside-in pattern recognition receptor signaling, regulating innate immune receptors and thereby playing important roles in the control of pulmonary innate immunity.

Chronic obstructive pulmonary disease (COPD) will soon become one of the most important causes of morbidity and mortality worldwide [8]. Thus, in this disease, the roles of innate immune mechanisms are important and attract increasing attention. Chronic bacterial infections of the lower airways are common in COPD, and it was reported that altered structures in the lower respiratory tract present habitats for commensals such as $\mathrm{Mo}$ raxella catarrhalis [9]. The dysregulated host defense is a major player in COPD and, in recent years, innate sensing of pathogens and inflammasome activation have caught increased interest [10-14].

Cystic fibrosis (CF) is a genetic disease sharing several similarities with COPD, i.e. a persistent neutrophil-dominated inflammation of the airways often in combination with chronic infection [15]. Neutrophils accumulate and,

\section{KARGER}

E-Mail karger@karger.com

www.karger.com/jin
(C) 2016 S. Karger AG, Basel

$1662-811 X / 16 / 0082-0109 \$ 39.50 / 0$ 
as a result, DNA is abundant within the bronchi. Part of the DNA is attributed to the formation of neutrophil extracellular traps, a process that is subject to complex regulation $[16,17]$. Recently, bactericidal activity of extracellular DNA against Pseudomonas aeruginosa, a common respiratory pathogen in $\mathrm{CF}$, was described [18]. Antimicrobial proteins bound to neutrophil extracellular traps may have several roles, including antimicrobial activity, and they also protect these structures against degradation induced by bacterial nucleases [19]. It is exciting to see that novel roles for extracellular DNA in the airways continue to be unraveled.
The last article in this issue by Benedyk et al. [20] demonstrates the importance of Porphyromonas gingivalis and its proteases in the development of aspiration pneumonia. Even if this state of disease is not associated with chronic inflammation, the model presented shows how rapid the delicate environment of the lower airways can be devastated by invading bacteria.

Taken together, the delicate tuning of airway innate immunity is continuously challenged by the environment and is skewed during prolonged inflammation, as seen in asthma, CF and COPD. Many questions remain to be answered in this rapidly evolving field of research.

Heiko Herwald, Lund Arne Egesten, Lund

\section{References}

1 Valent P, Groner B, Schumacher U, SupertiFurga G, Busslinger M, Kralovics R, Zielinski C, Penninger JM, Kerjaschki D, Stingl G, Smolen JS, Valenta R, Lassmann H, Kovar H, Jäger U, Kornek G, Müller M, Sörgel F: Paul Ehrlich (1854-1915) and his contributions to the foundation and birth of translational medicine. J Innate Immun 2016;8:111-120.

$>_{2}$ de Boer JD, Yang J, van den Boogaard FE, Hoogendijk AJ, de Beer R, van der Zee JS, Roelofs JJ, van 't Veer C, de Vos AF, van der Poll T: Mast cell-deficient kit mice develop house dust mite-induced lung inflammation despite impaired eosinophil recruitment. J Innate Immun 2014;6:219-226.

3 Mills CD, Ley K, Buchmann K, Canton J: Sequential immune responses: the weapons of immunity. J Innate Immun 2015;7:443-449.

4 Grailer JJ, Kalbitz M, Zetoune FS, Ward PA: Persistent neutrophil dysfunction and suppression of acute lung injury in mice following cecal ligation and puncture sepsis. J Innate Immun 2014;6:695-705.

-5 Stenberg Å, Karlsson A, Feuk-Lagerstedt E, Christenson K, Bylund J, Oldenborg A, Vesterlund L, Matozaki T, Sehlin J, Oldenborg PA: Signal regulatory protein alpha is present in several neutrophil granule populations and is rapidly mobilized to the cell surface to negatively fine-tune neutrophil accumulation in inflammation. J Innate Immun 2014;6:553-560.

-6 Sawant KV, Xu R, Cox R, Hawkins H, Sbrana E, Kolli D, Garofalo RP, Rajarathnam K: Chemokine CXCL1-mediated neutrophil trafficking in the lung: role of CXCR2 activation. J Innate Immun 2015;7:647-658.
7 Choudhary S, Boldogh I, Brasier AR: Insideout signaling pathways from nuclear reactive oxygen species control pulmonary innate immunity. J Innate Immun 2016;8:143-155.

-8 Decramer M, Janssens W, Miravitlles M: Chronic obstructive pulmonary disease. Lancet 2012;379:1341-1351.

-9 Abdillahi SM, Bober M, Nordin S, Hallgren O, Baumgarten M, Erjefält J, WestergrenThorsson G, Bjermer L, Riesbeck K, Egesten A, Mörgelin M: Collagen VI is upregulated in COPD and serves both as an adhesive target and a bactericidal barrier for Moraxella $\mathrm{ca}$ tarrhalis. J Innate Immun 2015;7:506-517.

10 van Lieshout MH, Florquin S, van't Veer C, de Vos AF, van der Poll T: TIR-domain-containing adaptor-inducing interferon- $\beta$ (TRIF) mediates antibacterial defense during Gramnegative pneumonia by inducing interferonx03B3. J Innate Immun 2015;7:637-646.

11 Yoon CM, Nam M, Oh Y-M, Dela Cruz CS, Kang M-J: Mitochondrial regulation of inflammasome activation in chronic obstructive pulmonary disease. J Innate Immun 2016; 8:121-128.

12 Gültekin Y, Eren E, Özören N: Overexpressed NLRC3 acts as an anti-inflammatory cytosolic protein. J Innate Immun 2015;7:25-36.

13 Yang J, Zhang E, Liu F, Zhang Y, Zhong M, Li Y, Zhou D, Chen Y, Cao Y, Xiao Y, He B, Yang Y, Sun Y, Lu M, Yan H: Flagellins of Salmonella Typhi and nonpathogenic Escherichia coli are differentially recognized through the NLRC4 pathway in macrophages. J Innate Immun 2014;6:47-57.
14 Xiong Y, Murphy M, Manavalan TT, Pattabiraman G, Qiu F, Chang H-H, Ho I-C, Medve$\operatorname{dev}$ AE: Endotoxin tolerance inhibits Lyn and c-Src phosphorylation and association with Toll-like receptor 4 but increases expression and activity of protein phosphatases. J Innate Immun 2016;8:171-184.

15 O’Sullivan BP, Freedman SD: Cystic fibrosis. Lancet 2009;373:1891-1904.

- 16 Dwyer M, Shan Q, D’Ortona S, Maurer R, Mitchell R, Olesen H, Thiel S, Huebner J, Gadjeva M: Cystic fibrosis sputum DNA has NETosis characteristics and neutrophil extracellular trap release is regulated by macrophage migration-inhibitory factor. J Innate Immun 2014;6:765-779.

17 Nanì S, Fumagalli L, Sinha U, Kamen L, Scapini P, Berton G: Src family kinases and Syk are required for neutrophil extracellular trap formation in response to $\beta$-glucan particles. J Innate Immun 2015;7:59-73.

18 Halverson TW, Wilton M, Poon KK, Petri B, Lewenza S: DNA is an antimicrobial component of neutrophil extracellular traps. PLoS Pathog 2015;11:e1004593.

19 Neumann A, Völlger L, Berends ET, Molhoek EM, Stapels DA, Midon M, Friães A, Pingoud A, Rooijakkers SH, Gallo RL, Mörgelin M, Nizet V, Naim HY, von Köckritz-Blickwede M: Novel role of the antimicrobial peptide LL37 in the protection of neutrophil extracellular traps against degradation by bacterial nucleases. J Innate Immun 2014;6:860-868.

20 Benedyk M, Mydel PM, Delaleu N, Płaza K, Gawron K, Milewska A, Maresz K, Koziel J, Pyrc K, Potempa J: Gingipains: critical factors in the development of aspiration pneumonia caused by Porphyromonas gingivalis. J Innate Immun 2016;8:185-198. 